\title{
Combined Effects of Compost and Medicago Sativa in Recovery a PCB Contaminated Soil
}

\author{
Martina Di Lenola ${ }^{1}$, Anna Barra Caracciolo ${ }^{1, *(1)}$, Valeria Ancona ${ }^{2}$, Vito Armando Laudicina ${ }^{3}$, \\ Gian Luigi Garbini ${ }^{1}$, Giuseppe Mascolo ${ }^{2}$ (D) and Paola Grenni ${ }^{1}$ (D) \\ 1 National Research Council, Water Research Institute (IRSA-CNR), Area della Ricerca RM1, Monterotondo, \\ 00015 Rome, Italy; dilenola@irsa.cnr.it (M.D.L.); garbini@irsa.cnr.it (G.L.G.); grenni@irsa.cnr.it (P.G.) \\ 2 National Research Council, Water Research Institute (IRSA-CNR), Viale Francesco de Blasio, 5, 70132 Bari, \\ Italy; valeria.ancona@ba.irsa.cnr.it (V.A.); giuseppe.mascolo@ba.irsa.cnr.it (G.M.) \\ 3 Università degli Studi di Palermo, Dipartimento Scienze Agrarie e Forestali, Viale delle Scienze, \\ 90128 Palermo, Italy; vitoarmando.laudicina@unipa.it \\ * Correspondence: barracaracciolo@irsa.cnr.it
}

Received: 21 January 2020; Accepted: 17 March 2020; Published: 19 March 2020

check for updates

\begin{abstract}
The effectiveness of adding compost and the plant Medicago sativa in improving the quality of a soil historically contaminated by polychlorinated biphenyls (PCBs) was tested in greenhouse microcosms. Plant pots, containing soil samples from an area contaminated by PCBs, were treated with the compost and the plant, separately or together. Moreover, un-treated and un-planted microcosms were used as controls. At fixed times (1,133 and 224 days), PCBs were analysed and the structure (cell abundance, phylogenetic characterization) and functioning (cell viability, dehydrogenase activity) of the natural microbial community were also measured. The results showed the effectiveness of the compost and plant in increasing the microbial activity, cell viability, and bacteria/fungi ratio, and in decreasing the amount of higher-chlorinated PCBs. Moreover, a higher number of $\alpha$-Proteobacteria, one of the main bacterial groups involved in the degradation of PCBs, was found in the compost and plant co-presence.
\end{abstract}

Keywords: plant-assisted bioremediation; microbial structure; microbial functioning; persistent organic pollutants; ELFA; FISH methods

\section{Introduction}

Soil microorganisms provide regulating ecosystem services, playing a central role in ensuring the quality of ecosystems. The presence of a rich and diverse microbial community makes it possible to recover soil from contamination [1,2]. However, soil remediation is possible if the detrimental effects of chemicals do not kill or inhibit microbial populations [3]. Particular concern arises from polychlorinated biphenyls (PCBs) which are persistent organic pollutants (POPs), as classified in the Stockholm Convention in 2001, and exclusively generated from anthropogenic sources. Although they have been prohibited since the 1970s, these POPs have been causing continuous exposition of water, air, sediments, soil and living organisms [4].

The most common PCB remediation strategies implemented today are "dig and dump" and "dig and incinerate" [5], but there is a need to apply effective green remediation strategies in line with environmental sustainability guidelines [6].

Laboratory experiments have recognized several bacterial pathways of PCB transformation. Lower halogenated PCBs $(\mathrm{Cl}<4)$ can be transformed by aerobic degradation. Higher halogenated PCBs $(\mathrm{Cl}>$ 4) can be reductively de-chlorinated in anaerobic conditions when organic compounds are present [7]. However, the occurrence of these bio-transformations is difficult to achieve in one environment. 
The biostimulation of PCB degradation can occur by adding compost to contaminated soil, because organic carbon sources can substantially increase their dechlorination [8]. Moreover, plants can help natural microorganisms in transforming, removing, and containing contaminants, including PCBs, in the plant-assisted bioremediation [9-13]. Inside the rhizosphere, microbial activity is promoted by root exudates, which comprise plant secondary metabolites that act as chemical signals and can stimulate the bacterial enzymes involved in PCB transformation [14-16]. In exchange, microorganisms produce molecules which are able to suppress plant pathogens or act as antibiotics $[17,18]$. Moreover, by exploring soil with their oxygen-transporting roots, plants offer the chance of exposing anoxic portion of soil to aerobic conditions, favouring the PCB oxidation with less than five chlorine atoms. Among plants identified for promoting PCB dissipation there are the Populus and Salix trees and the forage Medicago sativa [19-23]. M. sativa (alfalfa) is the primary, widely grown perennial legume in the world, a nitrogen fixing plant that has been found to help bacterial communities involved in PCB degradation [24-27]. Although adding compost and plants can improve in different ways the soil quality status, the pathways of PCB degradation, the environmental factors involved in their transformations, and the rhizosphere microbial community remain to be explored [28].

The objective of this research was to evaluate the effects of two treatments (i.e. biostimulation and plant-assisted bioremediation) in improving the soil quality and biodegradation of PCBs in microcosm experiments. For this purpose, a municipal solid waste compost and Medicago sativa seeds were added to soil samples collected from a PCB historically contaminated area. Soil microcosms with compost and/or plants were compared with respective untreated soil controls. The experimental set was maintained in a greenhouse for more than seven months. At fixed times, eighteen PCB congeners (six markers and twelve dioxin-like) were searched for. Moreover, the changes in the microbial community in terms of abundance, activity and composition were assessed.

\section{Materials and Methods}

\subsection{Soil Collection and Compost Description}

Soil was gathered from a PCB contaminated site, located in Apulia Region (Southern Italy), overlooking the Little Sea of Taranto, where a phytoremediation strategy, applying the Monviso poplar clone (Populus generosa $\times$ Populus nigra) as the main detoxifying plant, has been in progress for more than 4 years (Figure 1). The soil was previously analysed by the local Region Environmental Agency and a PCB concentration exceeding the National legal limit $\left(60 \mathrm{ng} \mathrm{g}^{-1}\right.$ for gardens, parks and residential areas, Italian D.Lgs. 152/06) was found in several points, with the highest values of $220 \mathrm{ng} \mathrm{g}^{-1}$ [10].

It was decided to sow Medicago sativa between poplar tree rows to improve soil recovery in terms of both fertility and PCB decontamination. An experiment with laboratory microcosms was set up to verify this strategy under controlled conditions.

The samples consisted of equal proportions of surface soil $(0-20 \mathrm{~cm})$ collected in three points in which PCB contamination was above the legislative limit of $60 \mathrm{ng} \mathrm{g}^{-1}$. Soil samples were prepared by eliminating stones and residues of plant roots dried at ambient temperature and sieved (2-mm mesh).

The main characteristics of the soil mix were soil $\mathrm{pH}$ (in water): 8; organic carbon content: ca. $1.5 \%$; total nitrogen: $0.02 \%$. The soil was a sandy loam in accordance with the USDA (United States Department of Agriculture) classification of particle-size fractions (https://www.nrcs.usda.gov/wps/ portal/nrcs/detail/soils/survey/?cid=nrcs142p2_054167). The municipal solid waste compost applied to the microcosm experiment was ISO/IEC 17025 certified. It was provided by the Italian Composters Consortium [29]. The microbiological characterization of the compost is reported in Table 1. 


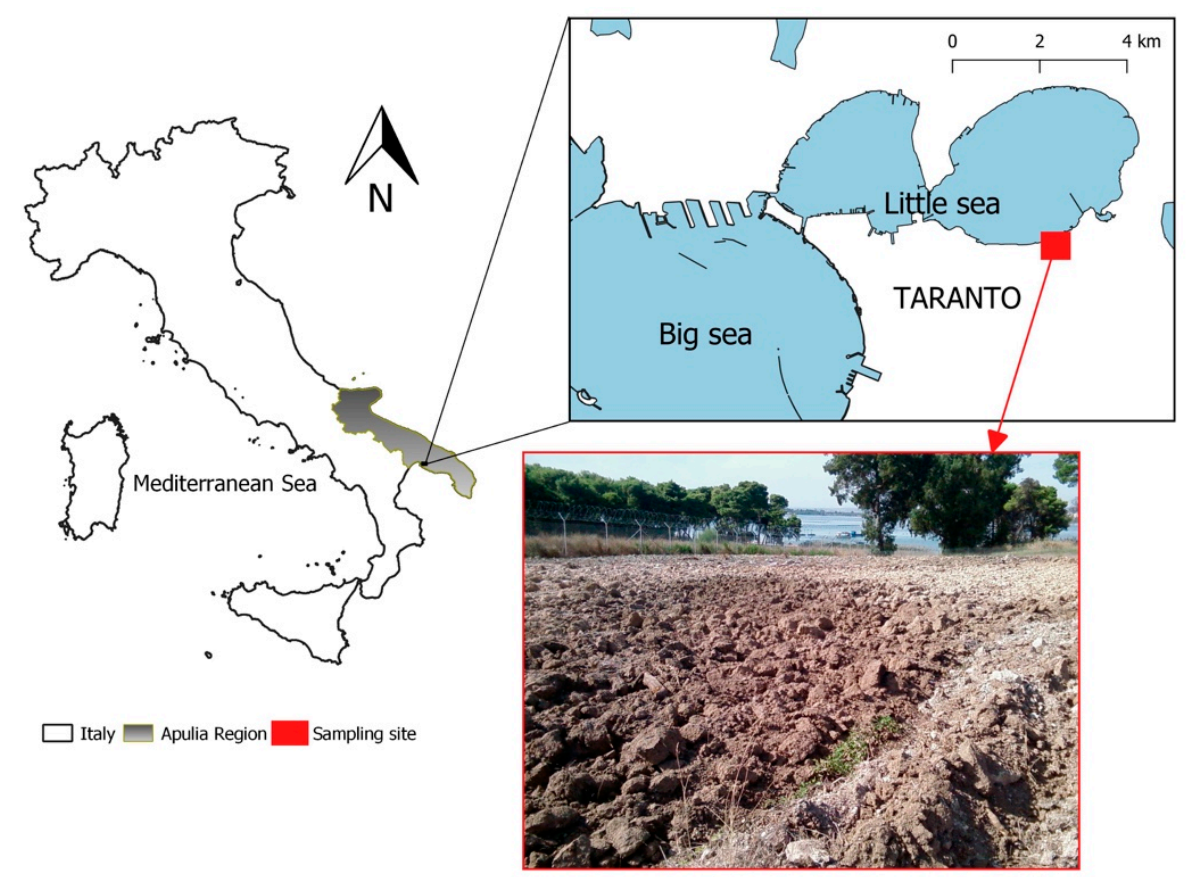

Figure 1. Location of the sampling site overlooking the Little Sea of Taranto.

Table 1. Municipal solid waste compost: microbiological parameters analysed in accordance with the legislation for fertilizers (Italian Decree 75/2010) for pathogens (E. coli and Salmonella) and additional ones (Microbial abundance, Cell viability and Dehydrogenase activity) assessed for its initial characterization before the addition to soil microcosms.

\begin{tabular}{ccc}
\hline & & Italian Legal Limits \\
\hline E. coli $\left(\mathrm{CFU} \mathrm{g}^{-1}\right)$ & $<25$ & $\leq 1000$ \\
Salmonella $\left(\mathrm{CFU} \mathrm{g}^{-1}\right)$ & Absent & Absent \\
\hline Microbial abundance $\left(\mathrm{No}\right.$ cells g $\left.{ }^{-1}\right)$ & $1.0 \times 10^{10}$ & - \\
Cell viability $\left(\%\right.$ live cells/live $+\mathrm{dead}^{10}$ & $3 \%$ & - \\
Dehydrogenase activity $\left(\mu \mathrm{g} \mathrm{TPF} \mathrm{g}^{-1}\right)$ & 550 & - \\
\hline
\end{tabular}

\subsection{Microcosm Set up}

Each plant pot microcosm $(1 \mathrm{~L})$ was filled with about $800 \mathrm{~g}$ of the composite soil. In twelve microcosms, only the historically contaminated soil was added. In another twelve pots, the same soil was previously mixed with compost (with a ratio 0.1 compost to 1 soil), which represented an agronomic compost dose of $26 \mathrm{t} \mathrm{ha}^{-1}$.

Lastly, Alfalfa seeds were sowed in half of the microcosms. Alfalfa was chosen for both its potential to enhance PCB dissipation and its ability to improve soil quality, being a nitrogen-fixing plant. For each different condition (i.e. HCS +/- plant and Compost +/- plant) six replicates (twenty-four microcosms in total) were performed. The experimental set was maintained for 224 days in a greenhouse $\left(18-22^{\circ} \mathrm{C}\right)$.

The four experimental conditions are summarized as follows:

- $\quad$ Historically contaminated soil = HCS;

- $\quad$ Historically contaminated soil + Alfalfa = Plant;

- $\quad$ Historically contaminated soil + Compost = Compost;

- $\quad$ Historically contaminated soil + Compost + Alfalfa $=$ Compost + Plant

The soil humidity was monitored in order to maintain it to ca. $60 \%$ of its field capacity. At each sampling, the microcosms (two replicates for each condition) were destructively collected. Each microcosm was divided in two parts: one was immediately processed for analysing the microbial cell 
abundance, viability and dehydrogenase activity at 1,133 and 224 days. The microbial structure was also evaluated by the fluorescence in situ hybridization (FISH) technique at the start and at the end of the experiment. The other part of soil was frozen $\left(-20^{\circ} \mathrm{C}\right)$ for the subsequent extraction of PCBs and ester-linked fatty acid (ELFA) analyses. Similar to FISH, the total ELFAs of the overall microbial community (including Fungi) was performed at 1 and 224 days.

At 133 and 224 days, when the seeds had grown and the roots completely filled the pots, soil and plants were sampled. In particular, roots and leaves were washed as described by Di Lenola et al. [29]. This washing step was performed to ensure that only the PCBs absorbed by the plant were measured. The water content of the plant tissue was measured by weighing fresh leaves $(10 \mathrm{~g})$ and roots $(1 \mathrm{~g})$, which were then oven-dried at $60^{\circ} \mathrm{C}$ for 3 days.

\subsection{Chemical Analysis of Specific PCB Congeners}

The PCB congeners analysed were the six markers $(28,52,101,138,153$, and 180) and the twelve dioxin-like $(77,81,105,118,114,123,126,156,157,167,169$, and 189), as recommended by EU Regulation No. 1259/2011. The first six PCBs are the most commonly found in the environment and represent those generally accumulated after a first biodegradation step. The second group of twelve PCBs, displaying toxicological properties similar to dioxins, can be harmful to health if found in feed and food. The congener numbers used are those defined by Ballschmiter and Zell [30].

The quantitative analyses of PCB congeners in soil and plant tissues were performed in accordance with the EPA method 1668. PCB extractions were performed by ASE (Accelerated Solvent Extraction) adopting the procedure reported in Thermo Scientific Technical note (210). Soil and plant tissue extracts were subsequently analysed using a Gas Chromatography coupled with a mass spectrometry (Thermo Scientific Finningan TRACE GC ultra), as described in detail by Ancona et al. [10].

The PCB degradation (\%) in soil was calculated for each PCB isomeric class/group (PCBs with the same chloride numbers) in accordance with how reported in Di Lenola et al. [29].

The bioaccumulation of PCBs in the plant roots and shoot tissues was calculated using the bioaccumulation factor $\left(\mathrm{BAF}_{\text {plant part }}=[\mathrm{PCB}]_{\text {plant part }} /[\mathrm{PCB}]_{\text {soil }}\right)$ for each PCB congener found [31].

\subsection{Microbiological Analyses}

Microbial abundance and cell viability were analysed using direct counting methods with an epifluorescence microscope (Leica DM4000B). The microbial abundance (No. cells $\mathrm{g}^{-1}$ dry soil) was assessed with DAPI stain as the binder of the double-stranded DNA, in fixed soil aliquots. Soil subsamples $(1 \mathrm{~g})$ from each microcosm were processed as reported in detail in Barra Caracciolo et al. [32].

The cell viability (\% live cells/live + dead) was evaluated in fresh soil subsamples $(1 \mathrm{~g})$. The two dyes used to measure the ratio of live to dead cells were propidium iodide and SYBR Green II (Sigma-Aldrich, Germany) respectively, as described in Grenni et al. [33,34].

Finally, the microbial activity ( $\mu \mathrm{g} \mathrm{TPFg}^{-1}$ dry soil) in soil samples was measured with the dehydrogenase assay. This method measures the red-coloured formazan (TPF) produced from the microbial reduction of 2,3,5- triphenyltetrazolium chloride (TTC). Soil sub-samples (5 g) were incubated at $37^{\circ} \mathrm{C}$ in the dark for $24 \mathrm{~h}$, and the TPF was colorimetrically determined at $485 \mathrm{~nm}$ with a spectrophotometer (Perkin-Elmer Lambda 40 UV/VIS spectrophotometer). Details of the method are reported in Grenni et al. [33,34].

\subsection{Structure of Microbial Community Assessed by ELFAs}

The ester-linked fatty acid (ELFA) analysis, one of the most successful biochemical methods for assessing microbial profiling and obtaining a taxonomic fingerprint of the main microbial groups (Gram-positive, Gram-negative bacteria and Fungi) occurring in a natural microbial community [1,35], was applied to soil sub-samples (3 g).

The relative abundance of fatty acids found in the different microcosm conditions was expressed as the mole percent (Mol \%) of total fatty acids. The ELFA 18:2w6,9c was used as the biomarker for 


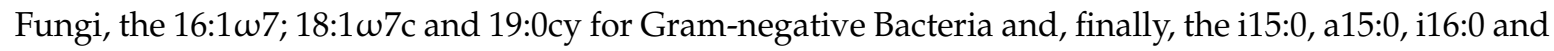
i17:0 for Gram-positive Bacteria [36,37]. This method was applied following the procedure described by Schutter and Dick [38] and Di Lenola et al. [29].

\subsection{Microbial Community Structure Assessed by FISH}

The fluorescence in situ hybridization (FISH) method was used for identifying under the epifluorescence microscope the structure of the active microbial community $[32,39,40]$. FISH was applied on fixed soil sub-samples $(1 \mathrm{~g})$, from each replicate microcosm, following the procedure described in detail in Barra Caracciolo et al. [41]. The fluorescent oligonucleotide probes applied were those for Archaea and Bacteria, and within the latter, those of the most frequently groups found in soil [39]. The list of the probes applied is shown in Table 2; they were labelled with a Cy3 or FAM fluorochrome at the $5^{\prime}$ end. The probe details are reported in Greuter et al. [42]. The evaluation of cells bound to the fluorescent probes was calculated as a percentage of the total DAPI positive cells (\% positive cells vs DAPI) and as the number of positive cells (No. positive cells $\mathrm{g}^{-1}$ soil).

\subsection{Statistical Analysis}

Each chemical and microbiological datum is the average value of the analysis performed in the two replicate microcosms per each sampling. The statistical analysis for assessing differences in PCB concentration (of total PCBs and of specific congeners), dehydrogenase activity and microbial abundance during the experimental period was performed using the two-way ANOVA analysis, with significant differences at the $p<0.05$ level. The time was always considered as variable 1 and the plant or compost occurrence as variable 2. The statistical analysis of ELFA and FISH data was achieved using the one-way ANOVA with treatment as the experimental factor. The statistical analysis Software used was SigmaStat.

\section{Results}

\subsection{Chemical Analysis}

The results of the chemical determinations of PCBs ( $\mathrm{ng} \mathrm{g}^{-1}$ soil) in the different soil microcosms (HCS, Compost, Plant, Compost + Plant) and at the different sampling times (1, 133, and $224 \mathrm{~d})$ are shown in Figure 2. PCBs 138, 153, 180, and the dioxin-like PCB 118 were generally the most abundant congeners found in all conditions. The congeners 77, 81, 123, 114, 169, and 189 were not found in the soil samples, possibly as they were not present or under the detection limits.

At day 224 the lower-chlorinated PCBs diminished by over half of their starting concentration $(p<0.01)$ in all microcosms, including in the control ones (HCS), (Figure 2, Table 3). A sharp reduction $(p<0.05)$ in the higher-chlorinated PCBs $(\mathrm{Cl}$ number $>4)$ was observed in Compost, Plant and Compost + Plant (Table 3) if compared to HCS. In the Compost and Compost + Plant treatments, congeners 105 and 156 decreased significantly more than in the Plant condition $(p<0.01)$, (Figure 2).

In order to calculate the bioaccumulation factor (BAF), for defining the ratio of PCB amount in plant tissue linked to PCB amount in the soil, the analysis in plant tissues (leaves, stems) and roots was performed at the end of the experiment in the case of the Compost + Plant microcosms. Unfortunately, in the Plant microcosms, the Alfalfa died up a few days before the last sampling. This was because the plant was at the end of its life cycle, which was presumably extended when the compost was added to the soil (Compost + Plant microcosms). 
Table 2. Probe sequences, target sites for each probe, and \% formamide used (stringency).

\begin{tabular}{|c|c|c|c|c|c|}
\hline Probe Name & $\begin{array}{l}\text { Short } \\
\text { Name }\end{array}$ & Specificity * & Sequence from $5^{\prime}$ to $3^{\prime}$ & $\begin{array}{l}\text { Target Molecule and } \\
\text { rRNA Position }\end{array}$ & Stringency $(\%)$ \\
\hline ARCH915 & $\mathrm{ARCH}$ & Archaea & GTGCTCCCCCGCCAATTCCT & 16S rRNA, 915-934 & 20 \\
\hline EUB338 ** (EUB) & EUB & Most Bacteria & GCTGCCTCCCGTAGGAGT & $16 \mathrm{~S}$ rRNA, 338-355 & 20 \\
\hline EUB338 II ** & EUB & Planctomycetales & GCAGCCACCCGTAGGTGT & 16S rRNA, 338-355 & 20 \\
\hline EUB338 III ** & EUB & Verrucomicrobiales & GCT GCC ACC CGT AGG TGT & 16S rRNA, 338-355 & 20 \\
\hline ALF1b & A & $\begin{array}{c}\alpha-\text { Proteobacteria, some Deltaproteobacteria, } \\
\text { Spirochaetes }\end{array}$ & CGT TCG (CT) TC TGA GCC AG & 16S rRNA, $19-35$ & 20 \\
\hline BET42a $\S$ & B & $\beta$-Proteobacteria & GCC TTC CCA CTT CGT TT & $23 S$ rRNA, 1027-1043 & 35 \\
\hline GAM42a ${ }^{\circ}$ & $\Gamma$ & $\gamma$-Proteobacteria & GCC TTC CCA CAT CGT TT & $23 \mathrm{~S}$ rRNA, 1027-1043 & 35 \\
\hline DELTA495a ^ & \multirow{3}{*}{$\Delta$} & $\begin{array}{l}\text { Most } \delta \text {-Proteobacteria, most } \\
\text { Gemmatimonadetes }\end{array}$ & AGT TAG CCG GTG CTT CCT & 16S rRNA, 495-512 & 35 \\
\hline DELTA495b^ & & Some $\delta$-Proteobacteria & AGT TAG CCG GCG CTT CCT & 16S rRNA, 495-512 & 35 \\
\hline $\operatorname{DELTA}_{495 c^{\wedge}}$ & & Some $\delta$-Proteobacteria & AAT TAG CCG GTG CTT CCT & $16 \mathrm{~S}$ rRNA, 495-512 & 35 \\
\hline CF319a & $\mathrm{CF}$ & $\begin{array}{c}\text { Most Flavobacteria, some Bacteroidetes, some } \\
\text { Sphingobacteria }\end{array}$ & TGG TCC GTG TCT CAG TAC & 16S rRNA, 319-336 & 35 \\
\hline HGC69A & HGC & $\begin{array}{c}\text { Actinobacteria (Gram-positive bacteria with } \\
\text { high DNA G+C content) }\end{array}$ & TAT AGT TAC CAC CGC CGT & 23S rRNA, 1901-1918 & 35 \\
\hline LGC354A ** & \multirow{3}{*}{ LGC } & \multirow{3}{*}{$\begin{array}{c}\text { Firmicutes (Gram-positive bacteria with } \\
\text { low } \mathrm{G}+\mathrm{C} \text { content) }\end{array}$} & TGG AAG ATT CCC TAC TGC & 16S rRNA, 354-371 & 35 \\
\hline LGC354B ** & & & CGG AAG ATT CCC TAC TGC & $16 \mathrm{~S}$ rRNA, 354-371 & 35 \\
\hline LGC354C ** & & & CCG AAG ATT CCC TAC TGC & 16S rRNA, 354-371 & 35 \\
\hline
\end{tabular}

${ }^{*}$ Information from ProbeBase (http://probebase.csb.univie.ac.at). ${ }^{* *}$ The three EUB probes were mixed and used together; the three probes mix matched with $94 \%$ of the bacterial sequences available [43]. § The probe was used in combination with the unlabelled GAM42a competitor. ${ }^{\circ}$ The probe was used in combination with the unlabelled BET42a competitor. ^ The three DELTA probes were mixed and used together. ${ }^{* *}$ The three LGC probes were mixed and used together to detect most Firmicutes. 
Table 3. Removal percentages of the sum of PCB congeners grouped by number of $\mathrm{Cl}$ atoms at day 224 in the various treatments. HCS = historically contaminated soil; Compost = historically contaminated soil treated with compost; Plant $=$ historically contaminated soil with Alfalfa plant; Compost + Plant $=$ historically contaminated soil treated with the compost, in the presence of Alfalfa plant.

\begin{tabular}{cccccc}
\hline N. Chlorine & tri-Cl & tetra-Cl & penta-Cl & hexa-Cl & hepta-Cl \\
\hline HCS & $66 \% \pm 0.66$ & $66 \% \pm 0.74$ & $36 \% \pm 0.00$ & $2 \% \pm 0.12$ & $29 \% \pm 0.01$ \\
Compost & $60 \% \pm 0.39$ & $69 \% \pm 0.24$ & $52 \% \pm 2.54$ & $25 \% \pm 0.69$ & $46 \% \pm 0.48$ \\
Plant & $60 \% \pm 0.73$ & $70 \% \pm 0.15$ & $37 \% \pm 5.98$ & $20 \% \pm 0.93$ & $52 \% \pm 1.16$ \\
Compost + Plant & $54 \% \pm 0.91$ & $71 \% \pm 0.23$ & $53 \% \pm 2.20$ & $16 \% \pm 1.32$ & $44 \% \pm 1.44$ \\
\hline
\end{tabular}

Various residual concentrations of some congeners (i.e., PCBs 28, 52, 118, 138, 153, and 180), were found in roots and shoots. The BAF values in roots were $>1$ in the case of PCB 28 (9.40), PCB 52 (2.28), and PCB 118 (1.29), while in the shoots only one congener (PCB 101) was found (BAF =1.33).

\subsection{Microbial Abundance, Cell Viability and Dehydrogenase Activity}

The compost effect on microbial abundance was immediate. Just one day after the compost addition, the microbial abundance was higher than in the conditions without compost (HCS and Plant). In HCS and Plant conditions the values were comparable to those found in the soil before the experiment set up. In fact, the cell number (No. cells $\mathrm{g}^{-1}$ dry soil) increased significantly $(p<0.01)$ in the microcosms where the compost was added (day 1) compared to the other conditions (Figure 3).

The values of cell viability at day 1 were lower in the compost microcosms (Compost and Compost + Plant) than those in the HCS and Plant microcosms, in line with the fact that dead bacteria were added with the compost (see the low cell viability value for compost in Table 1). A positive effect from the compost and plant presence was observed at day 224, with the highest cell viability value in this condition (Compost + Plant: 60\% > Plant: 54\% > Compost: 51\% > HCS: 49\%), as shown in Figure 4.

Adding compost immediately affected microbial activity (Figure 5). At day 1, the dehydrogenase values were in fact significantly higher $(p<0.01)$ in the compost treated microcosms if compared with the HCS and Plant microcosms $\left(91 \mu \mathrm{g}\right.$ TPF g ${ }^{-1}$ for HCS and Plant vs $218 \mu \mathrm{g}$ TPF $\mathrm{g}^{-1}$ dry soil for Compost and Compost + Plant), while the plant enhanced the activity over time (Figure 5). 

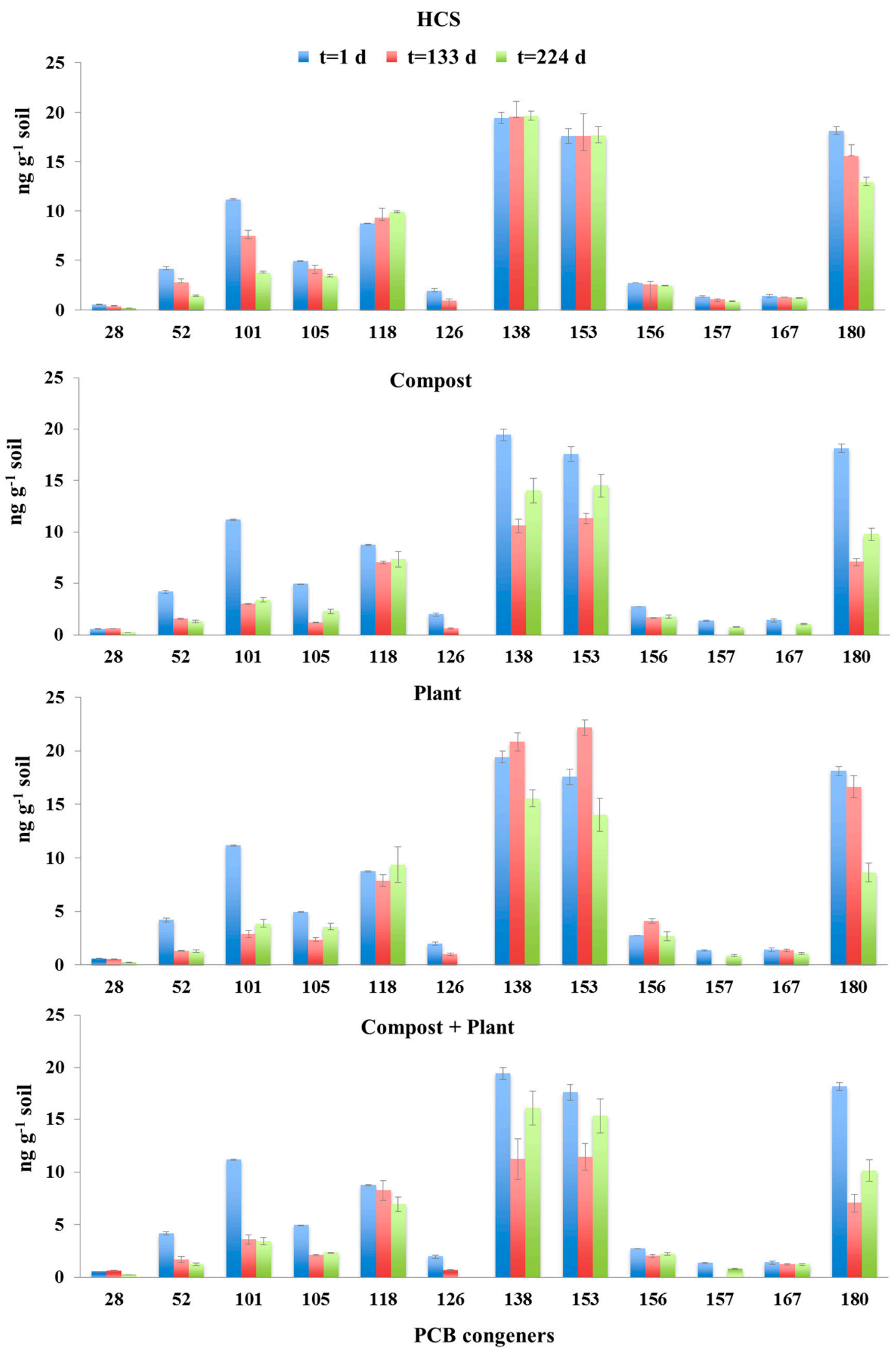

Figure 2. PCB congeners (ng g ${ }^{-1}$ soil) analysed at different times (1,133 and $224 \mathrm{~d}$ ) in the soil microcosms. HCS: historically contaminated soil; Compost: historically contaminated soil amended with municipal solid waste compost; Plant: historically contaminated soil with Medicago sativa plant; Compost + Plant: historically contaminated soil amended with the compost, in the presence of Medicago sativa plant. The vertical bars represent the standard errors. 


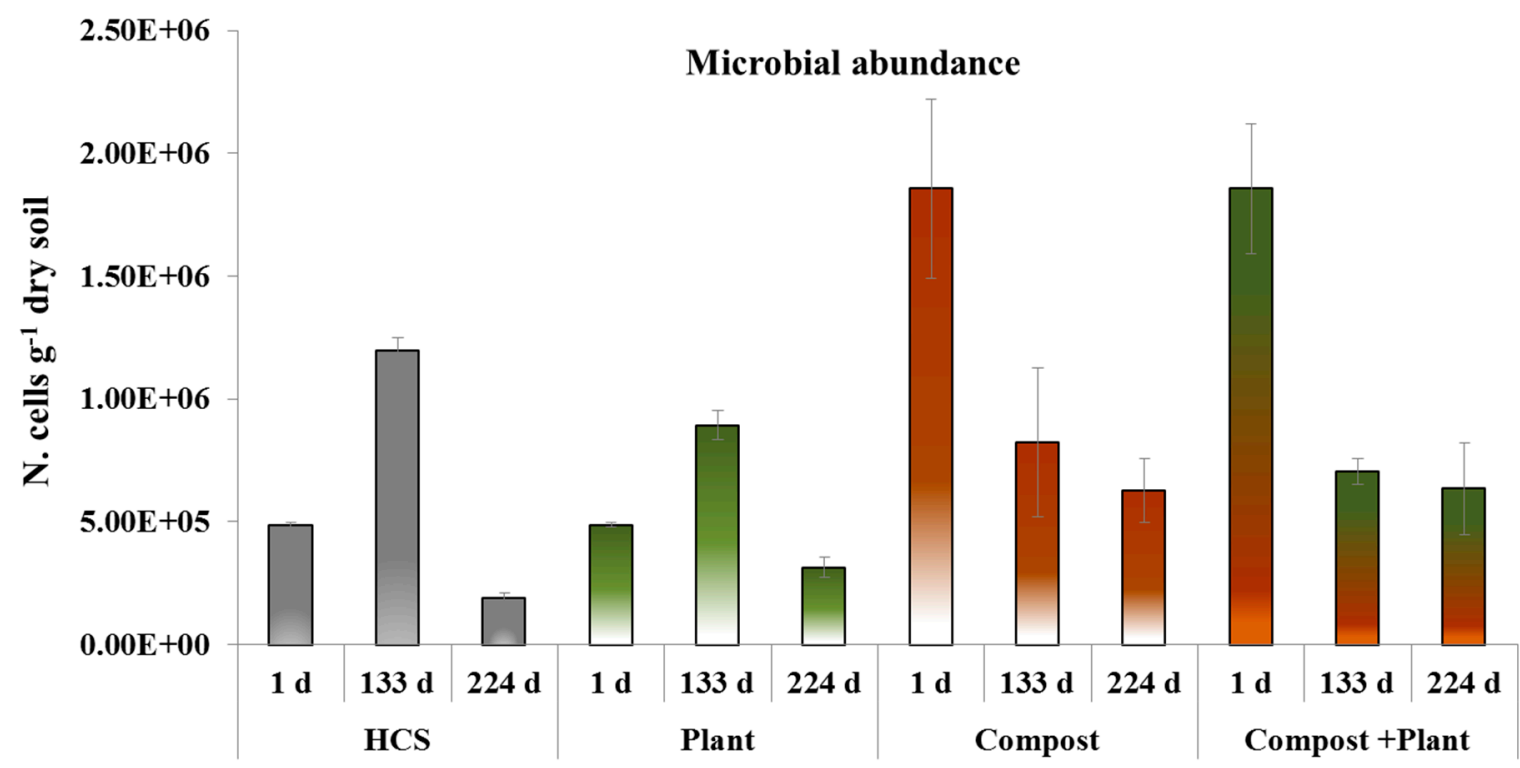

Figure 3. Microbial abundance (No. cells $\mathrm{g}^{-1}$ dry soil) in the three sampling times (days 1, 133 and 224). HCS: historically contaminated soil; Compost: historically contaminated soil amended with municipal solid waste compost; Plant: historically contaminated soil with Medicago sativa plant; Compost + Plant: historically contaminated soil amended with the compost, in the presence of Medicago sativa plant. The vertical bars represent the standard errors.

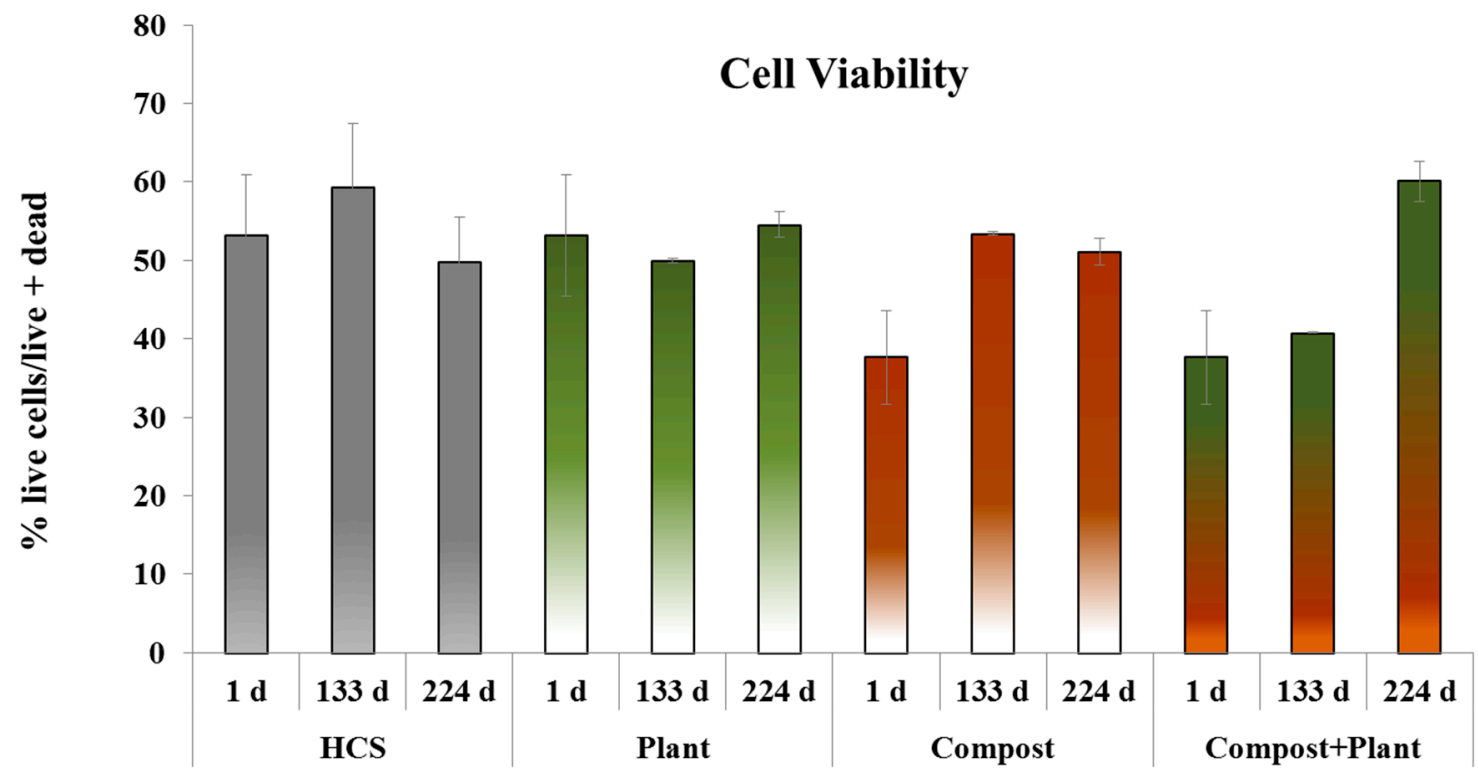

Figure 4. Cell viability (\% live cells/live + dead) in the three sampling times (days 1, 133 and 224). HCS: historically contaminated soil; Compost: historically contaminated soil amended with municipal solid waste compost; Plant: historically contaminated soil with Medicago sativa plant; Compost + Plant: historically contaminated soil amended with the compost, in the presence of Medicago sativa plant. The vertical bars represent the standard errors. 


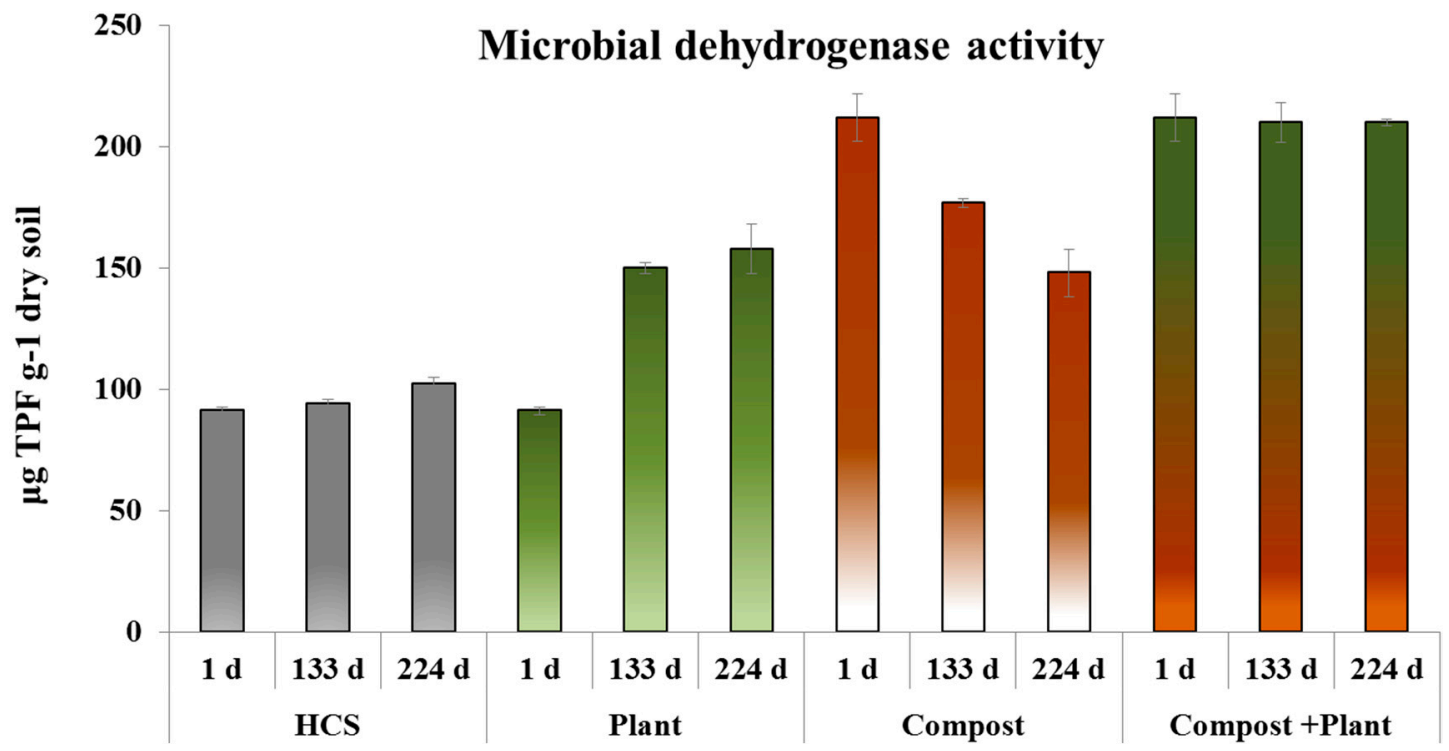

Figure 5. Microbial dehydrogenase activity ( $\mu \mathrm{g}$ TPF $\mathrm{g}^{-1}$ dry soil) over time (days 1, 133 and 224). HCS: historically contaminated soil; Compost: historically contaminated soil amended with municipal solid waste compost; Plant: historically contaminated soil with Medicago sativa plant; Compost + Plant: historically contaminated soil amended with the compost, in the presence of Medicago sativa plant. The vertical bars represent the standard errors.

Finally, the highest dehydrogenase values remained the same throughout the entire experimental period in only the Compost + Plant microcosms $(p<0.01)$, showing the synergic and long-term positive effect adding compost and $M$. sativa on the microbial community of the rhizosphere.

\subsection{Microbial Community Composition Evaluated Using ELFAs}

Eighteen individual ELFAs were identified and used to assess microbial biomass. Among them, the sums of the specific ELFAs detected were used as biomarkers: i15:0, a15:0, i16:0 and i17:0 were used for Gram-positive Bacteria, 16:1 $\omega 7 ; 18: 1 \omega 7 \mathrm{c}$ and 19:0cy for Gram-negative Bacteria and the sum

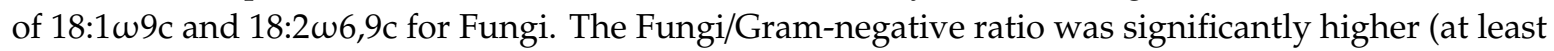
two-fold) at day 224 than at day 1 in all microcosms, while Gram-positive Bacteria and the microbial biomass were not significantly influenced by the treatments during the experimental time (data not shown). At 224 days, similar percentages of Gram-positive bacteria were found in all treatments, while Gram-negative ones were significantly lower in the plant presence. Fungi were significantly higher in the condition where both the plant and compost were present than in the other conditions (Figure 6).

The fungal polyunsaturated fatty acids $18: 1 \omega 9 \mathrm{c}$ and $18: 2 \omega 6,9 \mathrm{c}$ to Bacteria $(\mathrm{F} / \mathrm{B})$ ratio and the iso to anteiso $\mathrm{C} 15: 0$ biomarker (i/a) ratio showed the highest values of $\mathrm{F} / \mathrm{B}$ together with the lowest values of $\mathrm{i} / \mathrm{a}$ in the Plant and Compost + Plant conditions.

\subsection{Microbial Community Structure Analysed Using FISH}

At day 1 , the Bacteria domain had a percentage of $65.6 \pm 3.9 \%\left(6.4 \times 10^{5}\right.$ cells $^{-1}$ soil $)$. Inside this domain, the most abundant group was $\beta$-Proteobacteria $\left(1.6 \times 10^{5}\right.$ cells $\mathrm{g}^{-1}$ soil) then $\alpha$-Proteobacteria $\left(5.1 \times 10^{4}\right.$ cells g ${ }^{-1}$ soil), Bacteroidetes $\left(3.8 \times 10^{4}\right.$ cells g ${ }^{-1}$ soil $), \delta$-Proteobacteria $\left(2.5 \times 10^{4}\right.$ cells g ${ }^{-1}$ soil $)$ and $\gamma$-Proteobacteria $\left(1.3 \times 10^{4}\right.$ cells $\mathrm{g}^{-1}$ soil). Neither Archaea, nor Gram-positive bacteria (both HGC and LGC) were detected. At the end of the experiment a shift $(p<0.01)$ in the dominance of some bacterial groups was observed in the presence of the plant. In particular, $\alpha$-Proteobacteria significantly increased in the Plant and Compost + Plant microcosms, while $\beta$-Proteobacteria reduced drastically and $\delta$-Proteobacteria were never detected (Figure 7). 


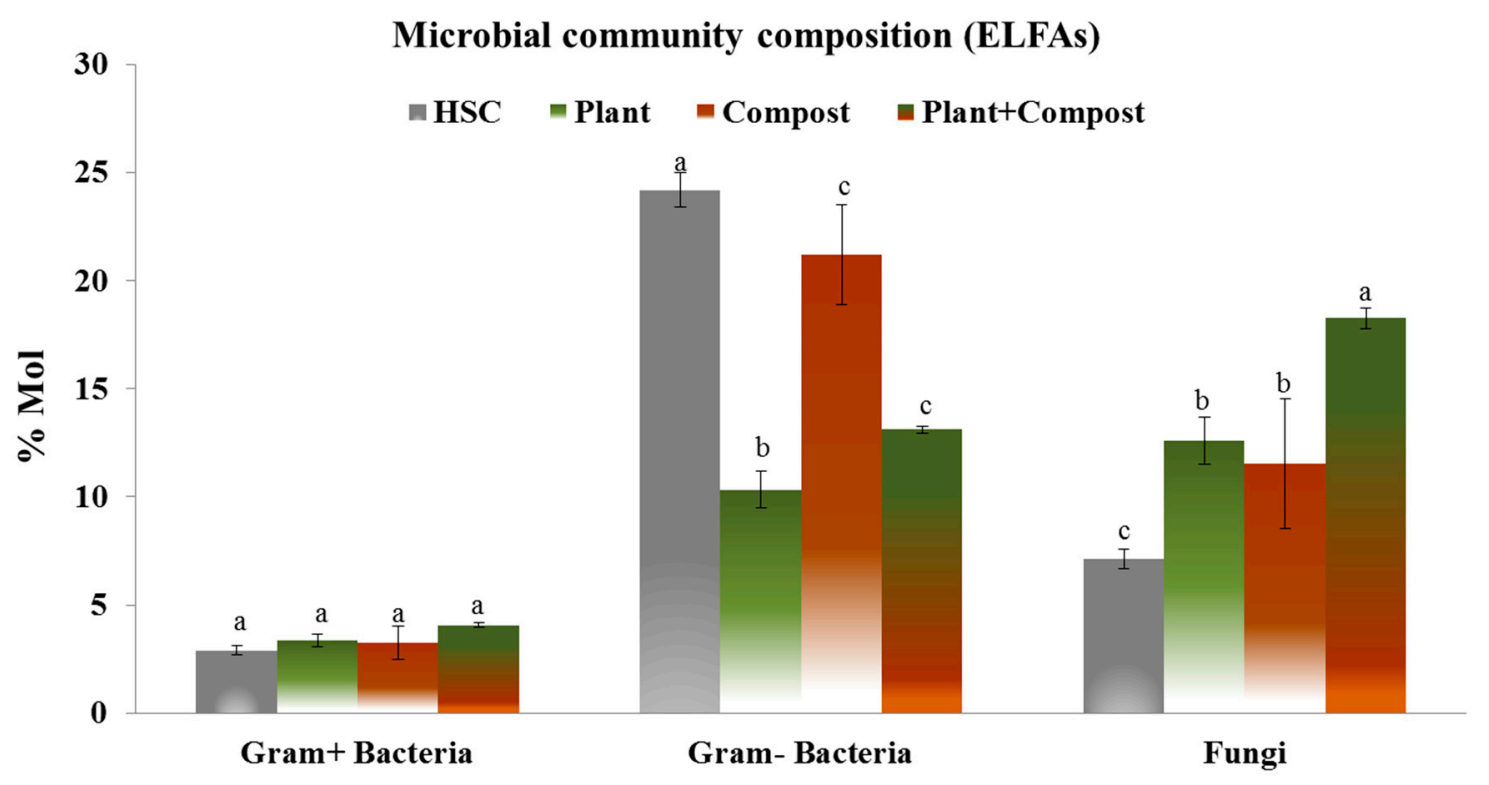

Figure 6. Microbial community structure assessed by ester-linked fatty acids (ELFA) expressed as \% Mol at day 224 in the different treatments. HCS: historically contaminated soil; Compost: historically contaminated soil amended with municipal solid waste compost; Plant: historically contaminated soil with Medicago sativa plant; Compost + Plant: historically contaminated soil amended with the compost, in the presence of Medicago sativa plant. The vertical bars represent the standard errors. Lowercase letters indicate significant differences $(p<0.05)$ among treatments within the same microbial group.

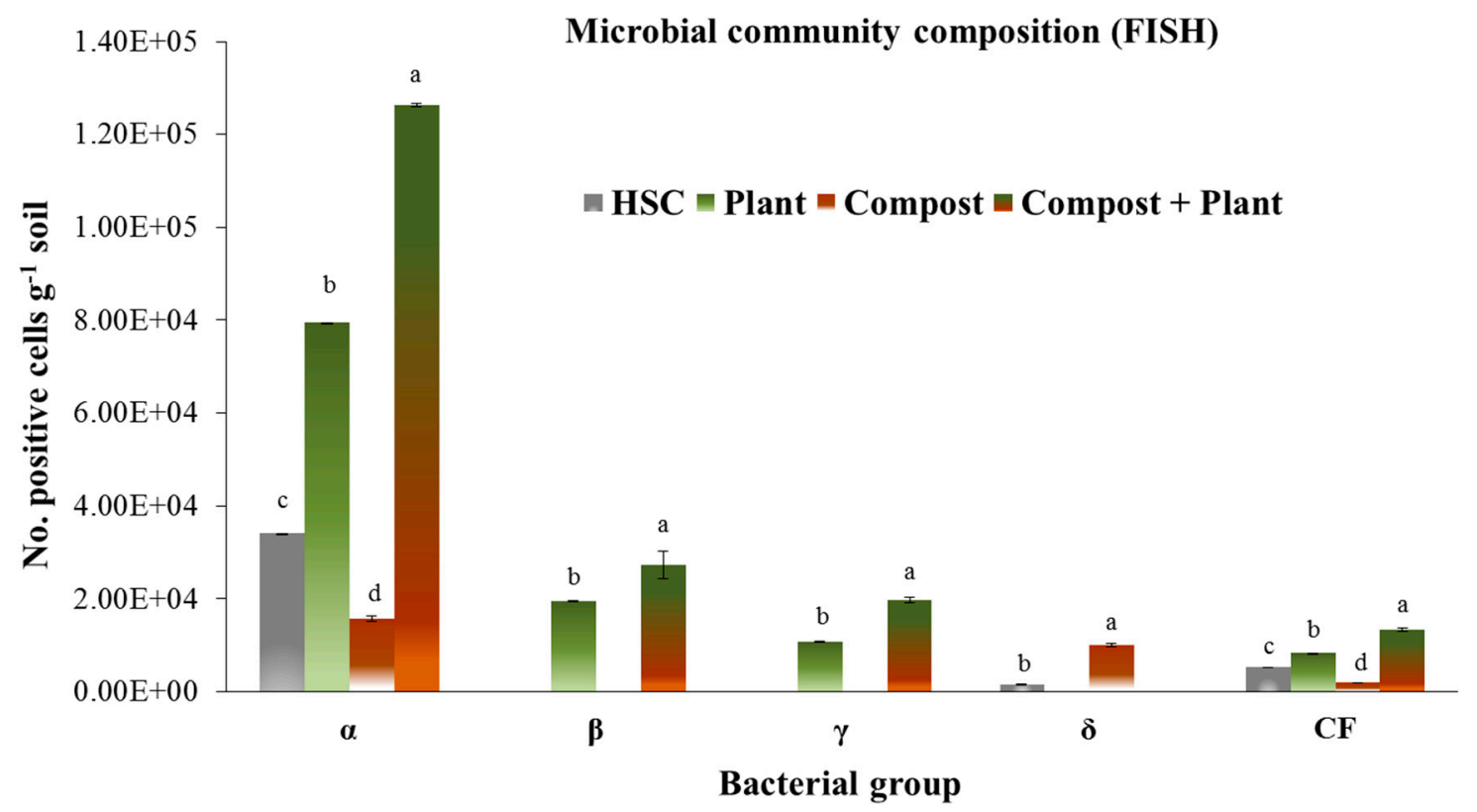

Figure 7. Microbial community structure assessed at day 224 in the various treatments by Fluorescence In Situ Hybridization (FISH), expressed as number of positive cells (No. positive cells $\mathrm{g}^{-1}$ soil). HCS: historically contaminated soil; Compost: historically contaminated soil amended with municipal solid waste compost; Plant: historically contaminated soil with Medicago sativa plant; Compost + Plant: historically contaminated soil amended with the compost, in the presence of Medicago sativa plant. $\alpha$ : $\alpha$-Proteobacteria; $\beta$ : $\beta$-Proteobacteria; $\gamma$ : $\gamma$-Proteobacteria; $\delta: \delta$-Proteobacteria; CF: Cytophaga-Flavobacterium-Bacteroidetes (CFB group). Lowercase letters indicate significant differences $(p<0.05)$ among treatments within the same microbial group. 


\section{Discussion}

PCB environmental contamination is a very complex issue, mainly because many different congeners are simultaneously present, and each congener can be transformed into another one by the addition/removal of one or more chlorine atoms. The resistance of PCBs to biodegradation varies in line with the molecular structure complexity, soil aging, texture, biological diversity and abundance, and abiotic factors affecting microbial activity (e.g., temperature, oxygen, and electron donors), [10,22,44].

The decrease in PCBs observed in both treated and untreated microcosms (although significantly lower in the latter ones) demonstrated the natural capability of the microbial autochthonous community in the soil studied to transform these molecules. At the end of the experiment, in fact, PCB28 and PCB52 decreased by more than $50 \%$ of their initial concentrations in all soils, including the untreated HCS. The decrease in lower halogenated PCBs, and in particular, of the 28 and 52 congeners, was probably due to the soil handling (e.g., sieving, watering) before the experiment set up, that stimulated aerobic microbial degradation. On the contrary, the degradation of higher-chlorinated PCBs (in particular $105,138,156$, and 180) was positively influenced by the plant and/or compost presence. The highest removal values for the penta, hexa, and hepta- $\mathrm{Cl}$ congeners, observed in soil treated with compost, plant, and compost plus plant, showed that these treatments were able to promote, although at different times and presumably in different ways, the bio-transformation of the higher-chlorinated PCBs, by activating both aerobic and anaerobic degradation pathways. Compost can be a carbon source for anaerobic dechlorination and, where co-present, can stimulate plant growth; the rhizosphere can directly stimulate PCB degradation through its exudates and indirectly provide a carbon source and/or microhabitat suitable for increasing microbial activity [45]. The increase (day 133) and subsequent decrease (day 224) in PCBs 138, 153, and 180 with a plant presence could be due to the decrease in the octo-chlorinated PCB194, which was indeed found in a high concentration ( $23 \mu \mathrm{g} \mathrm{kg}^{-1}$ soil) in the initial field site characterization and was later not found. PCB194 is in fact reported to be transformed into PCB180, and the latter in turn into PCB138 or 153 (hexa-Cl). PCB153 can be transformed into PCB101 (penta-Cl) and the latter into PCB52 (tetra-Cl) $[46,47]$. In similar experiments, the relative increase in some PCBs in aged soil with a plant presence was explained by the fact that root exudates can act as surfactants, binding PCBs and increasing their bioavailability in soil [27,48-50]. In any case, whatever the process involved, at day 224 the final PCB concentrations were lower than the initial ones, showing not only the effectiveness of Medicago sativa in stimulating their transformation, but also its positive effects on the structure and functioning of the soil natural microbial community. Compost and plants can directly and indirectly increase microbial diversity and stimulate microbial activity and contaminant degradation. The positive effect of applying compost on soil is ascribable to the presence of mineral and humidified organic matter, which can improve the soil aggregation and porosity and increase microbial activity and biomass [51-53]. The addition of organic matter through composted biosolid waste and planting of vegetation are strategies suited to the recovery and improvement of soil affected by erosion and/or contamination. In line with our results, other works report that Alfalfa plays a key role in promoting PCB dechlorination [29,54]. Furthermore, autochthonous microbial communities in PCB contaminated and aged soil can enhance the breakdown of PCBs in the rhizosphere [10,45,55-58]. Additionally, the rhizosphere and compost can serve as nutrient hotspots with a high microbial abundance, which promotes horizontal gene transfer [59].

The BAF values $>1$ found in roots in the case of the lower-chlorinated congeners (PCB 28 and $52)$ are in line with the results found with other plant species $[60,61]$. Owing to high hydrophobicity, PCB translocation through the transpiration stream of the plant is improbable. Moreover, the process of translocation relies on the ability of plants to take contaminants from the soil together with water and nutrients. This depends on the intrinsic chemical characteristics, such as solubility, $\mathrm{K}_{\mathrm{ow}}$ value etc. However, in some cases PCBs transportation in plants may occur if root exudates act as surfactants forming more hydrophilic complexes, as in the case of PCB 101, found in shoots in Compost + Plant microcosms. In any case, these complex interactions still have to be better investigated [22,60,61]. 
In this study, dehydrogenase activity was positively influenced by the treatments and particularly by the co-presence of compost and the plant, with a significant increase that was stable over a long period, in line with previous studies [33,34,62].

Similarly, the composition of the microbial community was positively influenced by the plant. In fact, an increase in the Fungi to Gram-negative Bacteria ratio was observed, in accordance with other studies. In particular Fungi are reported to improve soil quality even through positive modifications of the bacterial community $[63,64]$.

The highest increase in Fungi observed in the Compost+Plant microcosms was in line with the reported Medicago sativa symbiotic interactions with these microorganisms [65].

The iso to anteiso C15:0 biomarker (i/a) ratio is considered a soil quality and chemical stress indicator $[63,66,67]$. Therefore, the highest value of $\mathrm{i} / \mathrm{a}$ ratio found in HCS suggested a low soil quality ascribable to PCB presence and rhizosphere absence. ELFA analysis is a valuable culture-independent method for an overall description of community structure [68]. However, it produces a low taxonomic resolution [69]. The FISH analysis was therefore performed to investigate a little bit more in detail, the changes in microbial structure. The FISH results made it possible to identify which bacterial groups were positively affected by the Plant or compost or simultaneously by Plant and compost occurrence, i.e., $\alpha-, \beta-, \gamma$-Proteobacteria. Proteobacteria include most species engaged in the main biogeochemical cycles and are the most abundant phylum present in a good quality state soil $[39,70,71]$ and/or a soil with rhizosphere formation $[39,72,73]$. Lastly, the dominance and increase in $\alpha$-Proteobacteria, which includes many genera of nitrogen-fixing bacteria, can be ascribed to the Alfalfa capacity to support nitrogen fixing bacteria growth.

Finally, as regards the species that can be involved in PCB transformation, among $\alpha$ - (e.g., Spingomonas), $\beta$ - (e.g., Burkholderia, Alcaligenes, Achromobacter, Comamonas, Ralstonia), and $\gamma$-Proteobacteria (e.g., Pseudomonas, Acinetobacter), there are species reported to be able to degrade PCBs [74,75]. In some cases, the apparent discrepancy between the ELFA and FISH data for Gram-positive Bacteria was presumably because the FISH technique detects active bacteria with an adequate number of ribosomes $[39,40]$, while the ELFA one produces a phenotypic fingerprinting of microbial communities, whatever their activity.

\section{Conclusions}

The synergic effects of adding compost and plants in increasing soil quality in terms of microbial activity and structure, together with the degradation of the higher-chlorinated congeners of PCBs, were demonstrated. These results encourage the use of plant-assisted bioremediation in promoting PCB transformation. Further studies are needed to investigate the detailed pathways of microbial degradation of PCBs in the rhizosphere and for isolating bacterial strains that can be applied for bioaugmentation purposes.

Author Contributions: Conceptualization, M.D.L. and A.B.C.; Methodology, M.D.L.; A.B.C.; P.G.; V.A.L.; V.A.; G.M.; G.L.G.; Formal Analysis, M.D.L.; A.B.C.; P.G.; V.A.L.; V.A.; G.M.; G.L.G Data curation, M.D.L.; A.B.C.; P.G.; Writing-Original Draft Preparation, M.D.L. and A.B.C.; Writing-Review \& Editing, M.D.L, A.B.C.; P.G..; Project Administration, A.B.C. All authors have read and agreed to the published version of the manuscript.

Funding: This research was partially performed in the framework of the "Energy for Taranto- Technology And pRocesses for the Abatement of pollutaNts and the remediation of conTaminated sites with raw materials recovery and production of energy tOtally green (TARANTO)" project, funded by the Ministry of Education, University and Research, grant number ARS01_00637.

Acknowledgments: The Authors thank Francesca Falconi for her support in the microbiological analysis and Giuseppe Bagnuolo and Claudia Campanale for their help in the chemical analyses (CNR-IRSA). The authors also thank Jasmin Rauseo, Flavia Cattena and Ciro Galeone (CNR-IRSA) who contributed to some of the analyses.

Conflicts of Interest: The authors declare no conflict of interest. 


\section{References}

1. Laudicina, V.A.; Dennis, P.G.; Palazzolo, E.; Badalucco, L. Key biochemical attributes to assess soil ecosystem sustainability. In Environmental Protection Strategies for Sustainable Development; Malik, A., Grohmann, E., Eds.; Springer: Dordrecht, The Netherlands, 2012; pp. 193-227.

2. Barra Caracciolo, A.; Bottoni, P.; Grenni, P. Microcosm studies to evaluate microbial potential to degrade pollutants in soil and water ecosystems. Microchem. J. 2013, 107, 126-130. [CrossRef]

3. Babut, M.; Arts, G.H.; Barra Caracciolo, A.; Domange, N.; Friberg, N.; Gouy, V.; Grung, M.; Lagadic, L.; Martin-Laurent, F.; Mazzella, N.; et al. Pesticide risk assessment and management in a globally changing world - Report from a European interdisciplinary Workshop. Environ. Sci. Pollut. Res. 2013, 20, 8298-8312. [CrossRef]

4. Tehrani, R.; Van Aken, B. Hydroxylated polychlorinated biphenyls in the environment: Sources, fate, and toxicities. Environ. Sci. Pollut. Res. 2014, 21, 6334-6345. [CrossRef]

5. Gomes, H.I.; Dias-Ferreira, C.; Ribeiro, A.B. Overview of in situ and ex situ remediation technologies for PCB-contaminated soils and sediments and obstacles for full-scale application. Sci. Total. Environ. 2013, 445-446, 237-260. [CrossRef]

6. U.S. EPA. Superfund Green Remediation Strategy, U.S. Environmental Protection Agency, Office of Solid Waste and Emergency Response, Office of Superfund Remediation and Technology Innovation. 2010. Available online: https://www.epa.gov/sites/production/files/2016-01/documents/175857.pdf (accessed on 10 January 2019).

7. Song, M.; Luoa, C.; Li, F.; Jiang, L.; Wang, Y.; Zhangd, D. Anaerobic degradation of Polychlorinated Biphenyls (PCBs) and Polychlorinated Biphenyls Ethers (PBDEs), and microbial community dynamics of electronic waste-contaminated soil. Sci. Total. Environ. 2015, 502, 426-433. [CrossRef]

8. Semple, K.T.; Reid, B.J.; Fermor, T.R. Impact of composting strategies on the treatment of soils contaminated with organic pollutants. Environ. Pollut. 2001, 112, 269-283. [CrossRef]

9. Wenzel, W.W. Rhizosphere processes and management in plant-assisted bioremediation (phytoremediation) of soils. Plant Soil 2009, 321, 385-408. [CrossRef]

10. Ancona, V.; Barra Caracciolo, A.; Grenni, P.; Di Lenola, M.; Campanale, C.; Calabrese, A.; Uricchio, V.F.; Mascolo, G.; Massacci, A. Plant-assisted bioremediation of a historically PCB and heavy metal-contaminated area in Southern Italy. New Biotechnol. Part B 2017, 38, 65-73. [CrossRef]

11. Ancona, V.; Barra Caracciolo, A.; Campanale, C.; De Caprariis, B.; Grenni, P.; Uricchio, V.F.; Borello, D. Gasification treatment of poplar biomass produced in a contaminated area restored using plant assisted bioremediation. J. Environ. Manag. 2019, 239, 137-141. [CrossRef]

12. Fiorentino, N.; Mori, M.; Cenvinzo, V.; Duri, L.G.; Gioia, L.; Visconti, D.; Fagnano, M. Assisted phytoremediation for restoring soil fertility in contaminated and degraded land. Ital. J. Agron. 2018, 13 (Suppl. S1), 34-44.

13. Pino, N.J.; Munera, M.L.; Penuela, G.A. Phytoremediation of soil contaminated with PCBs using different plants and their associated microbial communities. Int. J. Phytoremediat. 2019, 21, 316-324. [CrossRef]

14. Glick, B.R. Using soil bacteria to facilitate phytoremediation. Biotechnol. Adv. 2010, 28, 367-374. [CrossRef]

15. Toussaint, J.P.; Pham, T.T.; Barriault, D.; Sylvestre, M. Plant exudates promote PCB degradation by a Rhodococcal rhizobacteria. Appl. Microbiol. Biotechnol. 2012, 95, 1589-1603. [CrossRef]

16. Qin, H.; Brookes, P.C.; Xu, J. Cucurbita spp. and Cucumis sativus enhance the dissipation of polychlorinated biphenyl congeners by stimulating soil microbial community development. Environ. Pollut. 2014, 184, 306-312. [CrossRef]

17. Doty, S.L. Enhancing phytoremediation through the use of transgenics and endophytes. New Phytol. 2008, 179, 318-333. [CrossRef]

18. Lugtenberg, B.; Kamilova, F. Plant-growth-promoting rhizobacteria. Ann. Rev. Microbiol. 2009, 63, 541-556. [CrossRef]

19. Dzantor, E.K.; Chekol, T.; Vough, L.R. Feasibility of using forage grasses and legumes for phytoremediation of organic pollutants. J. Environ. Sci. Health 2000, 35, 1645-1661. [CrossRef]

20. Mackova, M.; Prouzova, P.; Stursa, P.; Ryslava, E.; Uhlik, O.; Beranova, K.; Rezek, J.; Kurzawova, V.; Demnerova, K.; Macek, T. Phyto/rhizoremediation studies using long-term PCB-contaminated soil. Environ. Sci. Pollut. Res. 2009, 16, 817-829. [CrossRef] 
21. Ding, N.; Hayat, T.; Wang, J.E.; Wang, H.Z.; Liu, X.M.; Xu, J.M. Responses of microbial community in rhizosphere soils when ryegrass was subjected to stress from PCBs. J. Soils Sediments 2011, 11, 1355-1362. [CrossRef]

22. Terzaghi, E.; Zanardini, E.; Morosini, C.; Raspa, G.; Borin, S.; Mapelli, F.; Vergani, L.; Di Guardo, A. Rhizoremediation half-lives of PCBs: Role of congener composition, organic carbon forms, bioavailability, microbial activity, plant species and soil conditions, on the prediction of fate and persistence in soil. Sci. Total. Environ. 2018, 612, 544-560. [CrossRef]

23. Nogues, I.; Grenni, P.; Di Lenola, M.; Passatore, L.; Guerriero, E.; Benedetti, P.; Massacci, A.; Rauseo, J.; Barra Caracciolo, A. Microcosm experiment to assess the capacity of a poplar clone to grow in a PCB-contaminated soil. Water 2019, 11, 2220. [CrossRef]

24. Xu, L.; Teng, Y.; Li, Z.G. Enhanced removal of polychlorinated biphenyls from Alfalfa rhizosphere soil in a field study: The impact of a rhizobial inoculum. Sci. Total. Environ. 2010, 408, 1007-1013. [CrossRef]

25. Teng, Y.; Shen, Y.; Luo, Y.; Sun, X.; Sun, M.; Fu, D.; Li, Z.; Christie, P.J. Influence of Rhizobium meliloti on phytoremediation of polycyclic aromatic hydrocarbons by Alfalfa in an aged contaminated soil. J. Hazard. Mater. 2011, 186, 1271-1276. [CrossRef]

26. Li, Y.; Liang, F.; Zhu, Y.; Wang, F. Phytoremediation of a PCB-contaminated soil by alfalfa and tall fescue single and mixed plants cultivation. J. Soils Sediments 2013, 13, 925-931. [CrossRef]

27. Tu, C.; Ma, L.; Guo, P.; Song, F.; Teng, Y.; Zhang, H.; Luo, Y. Rhizoremediation of a dioxin-like PCB polluted soil by alfalfa: Dynamic characterization at temporal and spatial scale. Chemosphere 2017, 189, 517-524. [CrossRef] [PubMed]

28. Sylvestre, M.; Toussaint, J.P. Engineering microbial enzymes and plants to promote PCB degradation in soil: Current State of Knowledge. In Microbial Bioremediation of Nonmetals—Current Research; Koukkou, A.I., Ed.; Caister Academic: Norfolk, UK, 2011; pp. 177-196.

29. Di Lenola, M.; Barra Caracciolo, A.; Grenni, P.; Ancona, V.; Rauseo, J.; Laudicina, V.A.; Uricchio, V.F.; Massacci, A. Effects of Apirolio addition and Alfalfa and compost treatments on the natural microbial community of a historically PCB-contaminated soil. Water Air Soil Pollut. 2018, 229, 143. [CrossRef]

30. Ballschmiter, K.; Zell, M. Analysis of polychlorinated biphenyls (PCB) by glass capillary gas chromatography. Fresenius' Z. Anal. Chem. 1980, 302, 20-31. [CrossRef]

31. Whitfield Åslunda, M.L.; Rutter, A.; Reiner, K.J.; Zeeb, B.A. The effects of repeated planting, planting density, and specific transfer pathways on PCB uptake by Cucurbita pepo grown in field conditions. Sci. Total. Environ. 2008, 405, 14-25. [CrossRef]

32. Barra Caracciolo, A.; Giuliano, G.; Grenni, P.; Cremisini, C.; Ciccoli, R.; Ubaldi, C. Effect of urea on degradation of terbuthylazine in soil. Environ. Toxicol. Chem. 2005, 24, 1035-1040. [CrossRef]

33. Grenni, P.; Barra Caracciolo, A.; Rodríguez-Cruz, M.S.; Sanchez-Martin, M.J. Changes in the microbial activity in a soil amended with oak and pine residues and treated with linuron herbicide. Appl. Soil Ecol. 2009, 41, 2-7. [CrossRef]

34. Grenni, P.; Rodríguez-Cruz, M.S.; Herrero-Hernández, E.; Marín-Benito, J.M.; Sánchez-Martín, M.J.; Barra Caracciolo, A. Effects of wood amendments on the degradation of terbuthylazine and on soil microbial community activity in a clay loam soil. Water Soil Air Pollut. 2012, 223, 5401-5412. [CrossRef]

35. Hinojosa, M.B.; Parra, A.; Laudicina, V.A.; Moreno, J.M. Post-fire soil functionality and microbial community structure in a Mediterranean shrubland subjected to experimental drought. Sci. Total. Environ. 2014, 573, 1178-1189. [CrossRef]

36. Bossio, D.A.; Scow, K.M. Impacts of carbon and flooding on soil microbial communities: Phospholipid fatty acid profiles and substrate utilization patterns. Microb. Ecol. 1998, 35, 265-278. [CrossRef]

37. Zelles, L. Fatty acid patterns of phospholipids and lipopolysaccharides in the characterization of microbial communities in soil: A review. Biol. Fertil. Soils 1999, 29, 111-129. [CrossRef]

38. Schutter, M.E.; Dick, R.P. Comparison of fatty acid methyl ester (FAME) methods for characterizing microbial communities. Soil. Sci. Soc. Am. J. 2000, 64, 1659-1668. [CrossRef]

39. Barra Caracciolo, A.; Bustamante, M.A.; Nogues, I.; Di Lenola, M.; Luprano, M.L.; Grenni, P. Changes in microbial community structure and functioning of a semiarid soil due to the use of anaerobic digestate derived composts and rosemary plants. Geoderma 2015, 245-246, 89-97. [CrossRef] 
40. Di Lenola, M.; Grenni, P.; Proença, D.N.; Morais, P.V.; Barra Caracciolo, A. Comparison of two molecular methods to assess soil microbial diversity. In Soil Biological Communities and Ecosystem Resilience; Lukac, M., Grenni, P., Gamboni, M., Eds.; Springer International Edition: Berlin, Germany, 2017; pp. $25-42$.

41. Barra Caracciolo, A.; Grenni, P.; Cupo, C.; Rossetti, S. In situ analysis of native microbial communities in complex samples with high particulate loads. FEMS Microbiol. Lett. 2005, 253, 55-58. [CrossRef]

42. Greuter, D.; Loy, A.; Horn, M.; Rattei, T. probeBase-an online resource for rRNA-targeted oligonucleotide probes and primers: New features 2016. Nucleic Acids Res. 2016, 44, D586-D589. [CrossRef]

43. Amann, R.; Fuchs, B.M. Single-cell identification in microbial communities by improved fluorescence in situ hybridization techniques. Nat. Rev. Microbiol. 2008, 6, 339-348. [CrossRef]

44. Doick, K.J.; Klingelmann, E.; Buranuel, P.; Jones, K.C.; Semple, K.T. Long-term fate of polychlorinated biphenyls and polycyclic aromatic hydrocarbons in an agricultural soil. Environ. Sci. Technol. 2005, 39, 3663-3670. [CrossRef]

45. Chaudhry, Q.; Blom-Zandstra, M.; Gupta, S.K.; Joner, E.J. Utilising the synergy between plants and rhizosphere microorganisms to enhance breakdown of organic pollutants in the environment. Environ. Sci. Pollut. Res. Int. 2005, 12, 34-48. [CrossRef]

46. Field, J.A.; Sierra-Alvarez, R. Microbial transformation and degradation of polychlorinated biphenyls. Environ. Pollut. 2008, 155, 1-12. [CrossRef]

47. Meggo, R.E.; Schnoor, J.L. Cleaning Polychlorinated Biphenyl (PCB) Contaminated Garden Soil by Phytoremediation. Environ. Sci. 2013, 1,33-52. [CrossRef]

48. White, J.C.; Kottler, B.D. Citrate-mediated increase in the uptake of weathered 2,2-bis(p-chlorophenyl) 1,1-dichloroethylene residues by plants. Environ. Toxicol. Chem. 2002, 21, 550-556. [CrossRef]

49. White, J.C.; Mattina, M.I.; Lee, W.-Y.; Eitzer, B.D.; Mattina, M.I. Role of organic acids in enhancing the desorption and uptake of weathered p, p'-DDE by Cucurbita pepo. Environ. Pollut. 2003, 124, 71-80. [CrossRef]

50. Luo, L.; Zhang, S.Z.; Shan, X.Q.; Zhu, Y.G. Oxalate and root exudates enhance the desorption of p,pV-DDT from soils. Chemosphere 2006, 63, 1273-1279. [CrossRef]

51. Ros, M.; Hernández, M.T.; García, C. Soil microbial activity after restoration of a semiarid soil by organic amendments. Soil Biol. Biochem. 2003, 35, 463-469. [CrossRef]

52. Tejada, M.; Hernández, M.T.; García, C. Application of two organic amendments on soil restoration: Effects on the soil biological properties. J. Environ. Qual. 2006, 35, 1010-1017. [CrossRef]

53. Bastida, F.; Zsolnay, A.; Hernández, T.; García, C. Past, present and future of soil quality indices: A biological perspective. Geoderma 2008, 147, 159-171. [CrossRef]

54. Magee, K.D.; Michael, A.; Ullah, H.; Dutta, S.K. Dechlorination of PCB in the presence of plan nitrate reductase. Environ. Toxicol. Pharm. 2008, 25, 144-147. [CrossRef]

55. Macek, T.; Mackova, M.; Kas, J. Exploitation of plants for the removal of organics in environmental remediation. Biotechnol. Adv. 2000, 18, 23-34. [CrossRef]

56. Leigh, M.B.; Prouzová, P.; Macková, M.; MAcek, T.; Nagle, D.P.; Fletcher, J.S. Polychlorinated biphenyl (PCB)-degrading bacteria associated with trees in a PCB-contaminated site. Appl. Environ. Microbiol. 2006, 72, 2331-2342. [CrossRef] [PubMed]

57. Kuiper, I.; Lagendijk, E.L.; Bloemberg, G.V.; Lugtenberg, B.J. Rhizoremediation: A beneficial plant-microbe interaction. Mol. Plant-Microbe Interact. 2004, 17, 6-15. [CrossRef] [PubMed]

58. Yateem, A.; Al-Sharrah, T.; Bin-Haji, A. Investigation of microbes in the rhizosphere of selected grasses for rhizoremediation of hydrocarbon-contaminated soils. Soil Sediment Contam. 2007, 16, 269-280. [CrossRef]

59. van Elsas, J.D.; Bailey, M.J. The ecology of transfer of mobile genetic elements. FEMS Microbiol. Ecol. 2002, 42, 187-197. [CrossRef]

60. Huelster, A.; Mueller, J.F.; Marschner, H. Soil-plant transfer of polychlorinated dibenzo-p-dioxins and dibenzofurans to vegetables of the cucumber family (Cucurbitaceae). Environ. Sci. Technol. 1994, 28, 1110-1115. [CrossRef]

61. Ficko, S.A.; Rutter, A.; Zeeb, B.A. Potential for phytoextraction of PCBs from contaminated soils using weeds. Sci. Total. Environ. 2010, 408, 3469-3476. [CrossRef]

62. Crecchio, C.; Curci, M.; Pizzigallo, M.D.R.; Ricciuti, P.; Ruggiero, P. Effects of municipal solid waste compost amendments on soil enzyme activities and bacterial genetic diversity. Soil Biol. Biochem. 2004, 36, 1595-1605. [CrossRef] 
63. Stella, T.; Covino, S.; Burianová, E.; Filipová, A.; Křesinová, Z.; Vořřšková, J. Chemical and microbiological characterization of an aged PCB-contaminated soil. Sci. Total. Environ. 2015, 533, 177-186. [CrossRef]

64. Thijs, S.; Sillen, W.; Rineau, F.; Weyens, N.; Vangronsveld, J. Towards an Enhanced Understanding of Plant-Microbiome Interactions to Improve Phytoremediation: Engineering the Metaorganism. Front. Microbiol. 2016, 7, 341. [CrossRef]

65. Gallego-Giraldo, L.; Jikumaru, Y.; Kamiya, Y.; Tang, Y.; Dixon, R.A. Selective lignin downregulation leads to constitutive defense response expression in Alfalfa (Medicago sativa L.). New Phytol. 2011, 190, 627-639. [CrossRef] [PubMed]

66. Pinkart, H.C.; Ringelberg, D.B.; Piceno, Y.M.; Macnaughton, S.J.; White, D.C. Biochemical approaches to biomass measurements and community structure analysis. In Manual of Environmental Microbiology; Hurst, C.J., Crawford, R.L., Knudsen, G.R., McInerney, M.J., Stetzenbach, L.D., Eds.; American Society for Microbiology Press: Washington, DC, USA, 2002; pp. 101-113.

67. Ben-David, E.A.; Zaady, E.; Sher, Y.; Nejidat, A. Assessment of the spatial distribution of soil microbial communities in patchy arid and semi-arid landscapes of the Negev Desert using combined PLFA and DGGE analyses. FEMS Microbiol. Ecol. 2011, 76, 492-503. [CrossRef] [PubMed]

68. Nannipieri, P.; Ascher, J.; Ceccherini, M.T.; Landi, L.; Pietramellara, G.; Renella, G. Microbial diversity and soil functions. Eur. J. Soil Sci. 2013, 54, 655-670. [CrossRef]

69. Frostegård, Å.; Tunlid, A.; Bååth, E. Use and misuse of PLFA measurements in soils. Soil. Biol. Biochem. 2011, 43, 1621-1625. [CrossRef]

70. Godoi, I.; Sene, L.; Barra Caracciolo, A. Assessment of the bacterial community structure in a Brazilian clay soil treated with atrazine. Ann. Microbiol. 2014, 64, 307-311. [CrossRef]

71. Yao, F.; Yang, S.; Wang, Z.; Wang, X.; Ye, J.; Wang, X.; De Bruyn, J.M.; Feng, X.; Jiang, Y.; Li, H. Microbial taxa distribution is associated with ecological trophic cascades along an elevation gradient. Front. Microbiol. 2017, 8, 2071. [CrossRef]

72. Singh, B.K.; Munro, S.; Potts, J.M.; Millard, P. Influence of grass species and soil type on rhizosphere microbial community structure in grassland soils. Appl. Soil. Ecol. 2007, 36, 147-155. [CrossRef]

73. Buée, M.; De Boer, W.; Martin, F.; van Overbeek, L.; Jurkevitch, E. The rhizosphere zoo: An overview of plant-associated communities of microorganisms, including phages, bacteria, archaea, and fungi, and of some of their structuring factors. Plant Soil 2009, 321, 189-212. [CrossRef]

74. Bedard, D.L.; Wagner, R.E.; Brennan, M.J.; Haberl, M.L.; Brown, J.F. Extensive degradation of Aroclors and environmentally transformed polychlorinated biphenyls by Alcaligenes eutrophus H850. Appl. Environ. Microbiol. 1987, 53, 1094-1102. [CrossRef]

75. Komancova, M.; Jurcova, I.; Kochankova, L.; Burkhard, J. Metabolic pathways of polychlorinated biphenyls degradation by Pseudomonas spp. Chemosphere 2003, 50, 537-543. [CrossRef] 